\title{
The Role of Motivation in Gendered Educational and Occupational Trajectories Related to Maths
}

\author{
Helen M. G. Watt* \\ University of Michigan, Ann Arbor, USA
}

\begin{abstract}
This study examined the continued gender imbalance in mathematics participation in senior high, which has implications for adolescents' future careers. It confirms persisting greater male participation in maths-related educational and occupational choices among this sample of Australian youth. Gendered course-taking in maths, along with participation intentions for maths-related careers, were explained using the Expectancy-Value framework of Eccles and colleagues (Eccles (Parsons) et al., 1983; Wigfield \& Eccles, 2000). The influences of maths-related self-perceptions, intrinsic and utility values, and perceived task difficulty were assessed using longitudinal data from a sample of 442 adolescents spanning Grades 9 through 11 in Sydney, Australia. Gendered mathsrelated self-perceptions and intrinsic values were the major influences on gendered educational participation in senior high maths, which subsequently predicted maths-related career aspirationsover and above prior mathematical achievement. Utility value showed a curvilinear relationship with maths-related occupational intentions moderated by gender, whereby girls with the highest utility values planned for highly maths-related careers, while boys with mid through high utility values planned similarly highly maths-related careers. Recommendations focus on ways to enhance participation in maths, especially for girls.
\end{abstract}

\section{Introduction}

There is a general consensus that more men are involved in highly maths-related careers than women. This has prompted research emphases directed at understanding boys' and girls' mathematical participation, such as within the ExpectancyValue framework of Eccles and colleagues (e.g., Eccles (Parsons) et al., 1983; Wigfield \& Eccles, 2000). Since Lucy Sells voiced social concerns about female "underparticipation" in maths courses by identifying maths as a "critical filter" which limits access to many high-status high-income careers (Sells, 1980), other

\footnotetext{
*Now located at Faculty of Education, Monash University, Clayton Campus, Wellington Road, Melbourne, VIC 3800, Australia. E-mail: helen.watt@education.monash.edu.au
} 
researchers have also argued that many females prematurely restrict their educational and career options by discontinuing their mathematical training in high school or soon after (Heller \& Parsons, 1981; Meece, Wigfield, \& Eccles, 1990), with fewer females electing to study maths in post-secondary education (Bridgeman $\&$ Wendler, 1991; Lips, 1992). In the Australian context, the plethora of government policy documents and reports targeting girls' maths education also testifies to a general concern with girls' lower mathematical participation at school (see Leder \& Forgasz, 1992, for a review of these curricular and professional development initiatives). This is seen as socially important both from a utilitarian "waste of talent" perspective, as well as one of social justice, since many girls do not share equally in the advantages of the mathematically well prepared.

Over the last decade, we have seen an increasing trend in educational research, policy initiatives, and the media focusing on boys' educational needs. In Australia, there is currently a strong climate of concern regarding boys' education and participation in domains sex-typed as feminine (a major example of this being the ongoing Inquiry into the Education of Boys by the Standing Committee on Employment, Education and Workplace Relations; Parliament of Australia, House of Representatives, commissioned on 21 March 2000 by the Minister for Education, Training and Youth Affairs, and O'Doherty, 1994), accompanied and often fuelled by media debate (see Foster, 2000, in Australia; Zevenbergen, 1998, in Germany). A similar pattern of debate is evident in the USA, where a recent long-term study found some evidence to suggest that boys suffer greater declines than girls in their maths-related perceptions through adolescence (Jacobs, Lanza, Osgood, Eccles, \& Wigfield, 2002). Those authors argued that this could lead to problematic outcomes for boys in terms of dropping out of academic settings such as college. These conclusions have been reexamined by Watt (2004) in an Australian study, where she identified remarkably stable gender differences favouring boys in maths-related perceptions throughout adolescence. Watt's study identified that girls exhibited more negative changes than boys through middle secondary school grades, for both perceptions about the difficulty of maths and expectations for mathematical success, although these recovered somewhat by Grade 11 . Findings such as these emphasise the importance of retaining a focus on girls' academic well-being alongside current emphases on boys' academic progress, and caution against concluding that it is boys who are necessarily most "at risk" through secondary school. The present study is a timely examination of the extent to which gendered maths participation is a continuing concern, and further assesses the key factors that explain the nature of this participation.

\section{Maths-Related Educational Choices}

For this study, choices of maths participation included planned and subsequent actual levels of maths preparation in senior high school, and further, the mathsrelatedness of planned careers, based on longitudinal data. Gendered senior high maths participation has been documented through the work of Eccles and colleagues in the United States (e.g., Eccles, 1985; Eccles (Parsons), 1984; Updegraff, Eccles, 
Barber, \& O’Brien, 1996), in terms of high-school course enrolments, as well as by other researchers in reviews of international gendered trends in specialised maths course-taking (e.g., Leder, 1992; Leder, Forgasz, \& Solar, 1996). However, the organisational structure of maths courses in US schools, where the majority of research in this area has been concentrated, does not lend itself as easily to the study of this phenomenon. Senior high maths participation in the United States has been operationalised primarily according to the number of senior high courses taken. Importantly in that context, a greater number of maths courses does not necessarily imply participation in increasingly higher order and more complex mathematics. This is because courses are structured around topic areas, rather than along an explicit underlying continuum of complexity. Although some topics are generally regarded as less difficult (e.g., general math, beginning algebra) while others are regarded as the most difficult (e.g., calculus and trigonometry), there is no formal classification of the difficulty levels for the various topic areas.

Ideally, what is required to assess level of senior high maths participation is a context where students' course choices explicitly reflect the extent of their participation in increasingly complex and demanding mathematics. This would permit a more fine-grained analysis of maths participation than has been possible for most research in this area. Such a situation exists in the state of New South Wales (NSW), Australia. This is an ideal location for studying gendered choices in terms of course enrolment, since the extent of mathematics participation can be effectively operationalised during senior high school years. Maths in NSW senior high years is hierarchically structured in terms of course demand and difficulty. In Grades 11 and 12 , students elect which one of five ordered levels of mathematics they wish to study, although this choice is supervised by staff - a process which may restrict students from their preference should their performance be incommensurate with their choice, particularly in cases where student achievement is low. It is therefore possible to measure students' level of participation in senior high mathematics according to which of the five levels of mathematics they elect to study. At the lowest difficulty level is Maths in Practice (MIP), followed by the basic but more demanding Maths in Society (MIS), with the difficulty increasing in unit value through 2-unit (2U), 3-unit (3U), and the most advanced 4-unit (4U) maths (MacCann, 1995). This provides a naturally occurring ordered metric for measuring students' participation in maths in senior high school.

In general within the NSW context, a greater proportion of boys than girls elects to study the highest $4 \mathrm{U}$ senior high maths course in senior years, while greater proportions of girls than boys elect the lowest MIP and MIS course levels. Figure 1 depicts State-wide percentages of boys and girls studying each level of maths in senior high school, as demonstrated by their Higher School Certificate (HSC) examination enrolment. The HSC is a State-wide series of external examinations undertaken in the final Grade 12, supplemented by within-school assessment tasks conducted over Grades 11 and 12, and the combined assessment result determines access to university courses and to other educational programmes. The lowest MIP level was introduced in 1991, and so statistics are reported here from 1991 onwards. ${ }^{1}$ A similar 


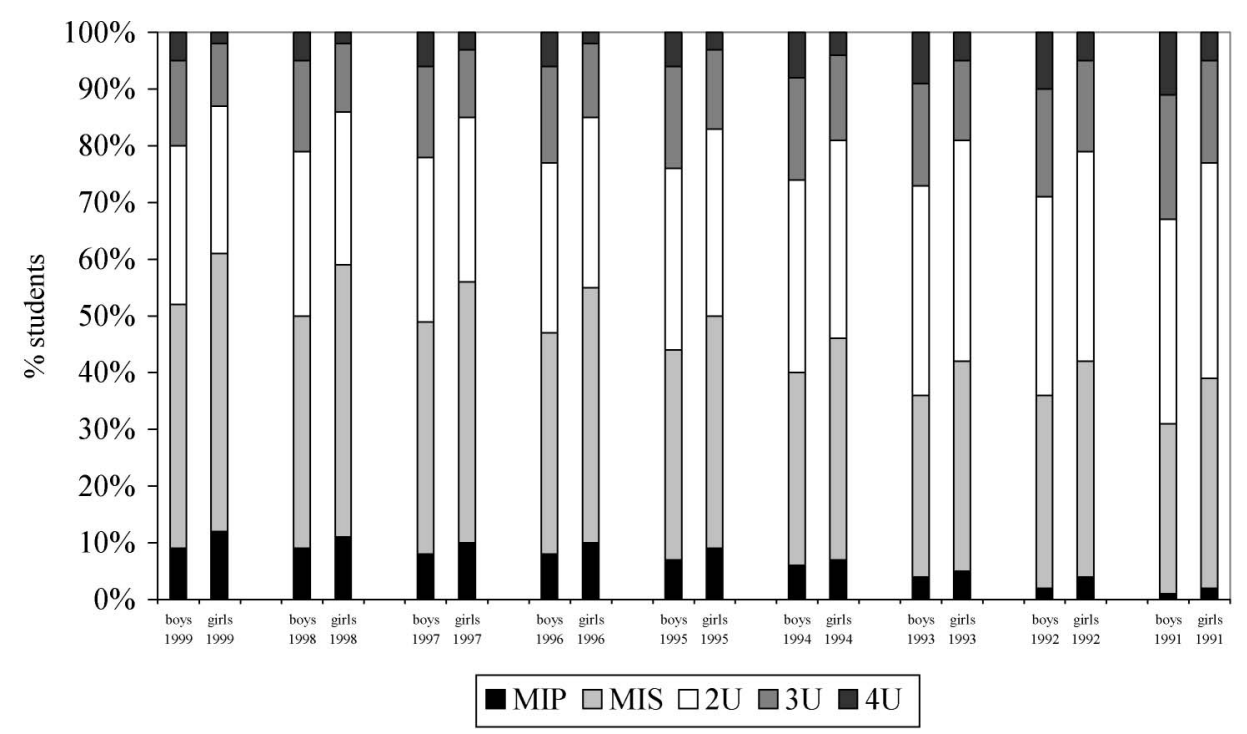

Figure 1. Gendered participation in senior high maths by course level in NSW 1991-1999. Note: Adapted from Board of Studies (1991, 1992, 1993, 1994, 1995, 1996, 1997, 1998, 1999)

pattern of greater male participation in the most demanding Grade 12 maths option in another Australian State, Victoria, has also recently been established (Forgasz \& Leder, 2001).

\section{Maths-Related Occupational Aspirations}

Measures of the maths-relatedness of adolescents' career intentions provide an important extension to our understanding of achievement-related choices beyond the high-school years. Quantification of career maths relatedness permits a further measurement of participation having clear social importance, and also extends the body of work within the Eccles et al. Expectancy-Value model (Eccles (Parsons) et al., 1983). Although limited career opportunities as a consequence of limited participation in mathematics have been widely recognised, there has been little study of relationships between these two aspects of maths participation, and an absence of empirical work establishing relationships between expectancies and values and maths participation in the form of mathematical career relatedness. In this study, maths career relatedness was operationalised using $\mathrm{O}^{*} \mathrm{NET}^{\mathrm{TM}} 98$ data (US Department of Labor Employment and Training Administration, 1998, for full details see Watt, 2002). The definition of career maths-relatedness used in $\mathrm{O}^{*} \mathrm{NET}^{\mathrm{TM}} 98$ is "using mathematics to solve problems", with classification codes ranging from "none", "any", "average" through to "high". Although a US reference, this is a comprehensive database based largely on data supplied by occupational analysts from sources such as the Dictionary of Occupational Titles (DOT) 
(see Osipow \& Fitzgerald, 1996, for an overview). To develop data for this database, analysts evaluated and refined existing occupational data, then applied these data to the $\mathrm{O}^{*} \mathrm{NET}^{\mathrm{TM}} 98$ content model. No such comprehensive Australian database is available in published form, and given the cultural similarity and career transferability across the two countries, this database was considered appropriate as a basis from which to perform career categorisations.

\section{Explaining Maths-Related Educational and Occupational Choices}

Expectancy-Value theory is one of the major frameworks for achievement motivation, and was developed to explain students' gendered choices and achievement in relation to maths (see Eccles (Parsons) et al., 1983; Wigfield \& Eccles, 2000, for an overview of this framework). Within it, success expectancies and the subjective valuation of success are the most proximal influences on achievement-related choices and behaviours, and these are in turn predicted by ability beliefs as well as perceived task demands.

Success expectancies have been defined by Eccles and colleagues (Eccles (Parsons) et al., 1983) as beliefs about how well one will perform on an impending task, and these are distinguished conceptually from ability beliefs, which are defined as perceptions of one's current competence at a given activity. However, Eccles and colleagues have not been able to distinguish empirically these ability and expectancies constructs (Eccles \& Wigfield, 1995; Wigfield \& Eccles, 2000). Elsewhere I have argued that this is likely to be due to ability perceptions mostly having been operationalised through broad questions asking students to rate their own performance in different areas (see Eccles \& Wigfield, 1995), such that their responses may depend partly on evaluations of their performance and partly on evaluations of their aptitude (see Watt, 2002, 2004, 2005). It has been claimed that natural talent is a concept that best represents the notion of ability distinct from performance (Bornholt et al., 1994, based on Green, 1974), and empirical support for the distinction between talent and ability perceptions as commonly operationalised in the literature has been provided by Watt (2002, 2004). Talent perceptions are theoretically different from ability perceptions operationalised as competence beliefs, as a student may well feel s/he performs well on a certain task, yet still not feel $\mathrm{s} / \mathrm{he}$ has a talent or aptitude for it. A higher order maths-related "self-perceptions" factor has also been validated, based on component talent perceptions and success expectancies (for details see Watt, 2002), and this is what is used in the present study, rather than ability perceptions as measured in the Expectancy-Value framework.

Values relate to how a task meets individual needs (Eccles (Parsons) et al., 1983; Wigfield \& Eccles, 1992), and the present study focuses on intrinsic and utility values. Intrinsic value is the enjoyment one gets from carrying out a given task, and utility value refers to how a task will be useful to an individual in the future (Wigfield \& Eccles, 2000). The work of Eccles, Wigfield, and colleagues has demonstrated that expectancies and values relate to achievement-related choices operationalised as course enrolment and also to achievement (e.g., Eccles, 1985; Eccles, Adler \& 
Meece, 1984; Eccles (Parsons), 1984; Eccles (Parsons) et al., 1983; Meece, Eccles (Parsons), Kaczala, Goff, \& Futterman, 1982; Meece et al., 1990; Wigfield, 1994; Wigfield \& Eccles, 1992). Eccles and colleagues have found values to emerge as powerful predictors of enrolment choices (e.g., Eccles et al., 1984; Eccles (Parsons) et al., 1983; Updegraff et al., 1996), while expectancies better predict performancefindings which have also been supported by other researchers (e.g., Bong, 2001). Some more recent studies have also demonstrated a link between expectancies and enrolment choices (e.g., Simpkins, Davis-Kean, \& Eccles, in press).

Less work has been done within this framework in relation to perceptions about the difficulty of a task (Eccles \& Wigfield, 1995). In the Expectancy-Value model, perceived task difficulty is posited to influence achievement-related outcomes via its influence on expectancies and values (Eccles (Parsons) et al., 1983; Wigfield \& Eccles, 2000), although these researchers acknowledge that there has been little research directly addressing the relationship between perceived difficulty and task choice. Perceived task difficulty is incorporated in this way in the present study, given its prominence in the Expectancy-Value model.

\section{The Present Study}

Goals of the present study were to use longitudinal data to first, establish the extent to which boys' maths participation exceeded girls' - both in senior high course intentions and selections, as well as their planned careers. The second goal was to examine the nature and extent of gender differences on adolescents' prior mathematical achievement, maths-related self-perceptions, intrinsic and utility values, and perceived task difficulty. Third, the influences of gender, self-perceptions, intrinsic and utility values, and perceived task difficulty on senior high and career maths participation choices were modelled, controlling for prior mathematical achievement.

\section{Method}

\section{Sample and Setting}

Participants $(N=459)$ spanned Grades 9 through 11 in a longitudinal design containing $43 \%$ females, and predominantly English Speaking Background (ESB) students $(73 \%)$, with the largest ethnic subgroup being Asians (22\%). Participants were from three upper-middle class coeducational secondary schools in northern metropolitan Sydney, matched for socioeconomic status according to the Index of Education and Occupation, based on census data (Australian Bureau of Statistics [ABS], 1991). Data were collected in February near the start of the Australian academic year from 1996 through 1998, when participants were in Grades 9 through 11. Maths achievement data were collected in the 1st year; maths intrinsic and utility values, self-perceptions related to maths, and perceptions of maths difficulty in the 2nd year; and maths participation choices for senior high and career intentions in all 3 
years. The present study was part of my larger study investigating a broader range of perceptions related to maths as well as English.

Sixty-five percent of participants were present at all three occasions, an additional $23 \%$ were present for two of the occasions, and $12 \%$ participated only at the first occasion. Table 1 shows the total numbers of participants who were present at each of the math administrations for each time-point. People with missing data on all relevant variables for the present study were omitted, following which missing data were imputed for prior achievement, intrinsic and utility values, self-perceptions, and perceptions of difficulty, using multiple imputation - a methodology that accounts for the uncertainty in estimating missing data (Schafer, 1997). No imputations were made for missing data in educational and occupational choices, at Grade 11. This resulted in reduced subsample sizes of 337 for the analysis predicting maths course enrolments, and 281 for maths-related career plans. Lower numbers for career plans were the result of a number of participants not knowing what careers they planned to pursue.

In the State of NSW, students attend secondary school Grades 7 through 12 . For maths, syllabi exist for each of Grades 7 and 8, 9 and 10, and 11 and 12. Junior Grades 7 and 8 are focused largely on consolidation of material learned through primary Grades 3 through 6, while in Grades 9 and 10 students are streamed into levels of "Advanced", "Intermediate", or "Standard" maths, based on their demonstrated ability up to that point. In senior Grades 11 and 12, which lead up to a major external examination supplemented by within-school assessment results called the Higher School Certificate (HSC), students elect which subjects they wish to study. English is the only required subject, although most students elect to study maths as this is perceived to be an important subject and is in fact a requirement for many tertiary courses. In addition to students selecting which academic subjects they wish to study for the HSC, they also select which difficulty level within their chosen subjects they wish to undertake. As outlined earlier, senior high maths course levels leading to the HSC range from the lowest Maths in Practice (MIP), through Maths in Society (MIS), 2-unit, 3-unit, and up to the highest 4-unit level.

\section{Materials}

Questionnaires assessed students' maths-related self-perceptions (a composite of their comparative talent perceptions and success expectancies, see Watt, 2002, 2004,

Table 1. Response rates across occasions

Total $N$

Grade 9

418

Grade 10

Grade 11
Maths $N$ 
for details), values (intrinsic and utility values), and perceived task difficulty. These were measured at Grade 10 - the year prior to when students selected their senior high maths course levels. Items were those modified by Watt (2004) based on those developed by Eccles and colleagues for success expectancies and intrinsic value (see Wigfield \& Eccles, 2000) and, as discussed earlier, perceptions of talent were assessed instead of their perceptions of ability factor. Full details of modifications and good construct validity and reliability based on the present sample are reported by Watt (2002, 2004), and sample items are presented in Table 2. Correlations among constructs are summarised in Table 3. Prior mathematical achievement was measured at Grade 9 out of a possible total score of 28, using Standardized Progressive Achievement Tests (Australian Council for Educational Research (ACER), 1984).

Table 2. Sample construct items

\begin{tabular}{|c|c|c|}
\hline Construct & Sample item & Anchors \\
\hline \multicolumn{3}{|l|}{ Self-perceptions } \\
\hline $\begin{array}{l}\text { - Comparative talent } \\
\text { perceptions }\end{array}$ & $\begin{array}{l}\text { Compared with other students in } \\
\text { your class, how talented do you } \\
\text { consider yourself to be at maths? }\end{array}$ & $\begin{array}{l}1 \text { (not at all) - } \\
7 \text { (very talented) }\end{array}$ \\
\hline - Success expectancies & $\begin{array}{l}\text { How well do you expect to do in } \\
\text { your next maths test? }\end{array}$ & $\begin{array}{l}1 \text { (not at all)- } \\
7 \text { (very well) }\end{array}$ \\
\hline \multicolumn{3}{|l|}{ Values } \\
\hline - Intrinsic value & $\begin{array}{l}\text { How much do you like maths, } \\
\text { compared with your other } \\
\text { subjects at school? }\end{array}$ & $\begin{array}{l}1 \text { (much less)- } \\
7 \text { (much more) }\end{array}$ \\
\hline - Utility value & How useful do you believe maths is? & $\begin{array}{l}1 \text { (not at all) - } \\
7 \text { (very useful) }\end{array}$ \\
\hline \multicolumn{3}{|l|}{ Task perceptions } \\
\hline - Perceived difficulty & How complicated is maths for you? & $\begin{array}{l}1 \text { (not at all) - } \\
7 \text { (very complicated) }\end{array}$ \\
\hline
\end{tabular}

Note: Underscorings appeared on the survey for emphasis.

Table 3. Pearson correlations among prior achievement, perceived difficulty, intrinsic value, utility value, and self-perceptions

\begin{tabular}{lllll}
\hline & $\begin{array}{c}\text { Prior } \\
\text { achievement }\end{array}$ & $\begin{array}{c}\text { Perceived } \\
\text { difficulty }\end{array}$ & $\begin{array}{c}\text { Intrinsic } \\
\text { value }\end{array}$ & $\begin{array}{c}\text { Utility } \\
\text { value }\end{array}$ \\
\hline Perceived difficulty & .02 & & \\
Intrinsic value & $.27^{* *}$ & $-.44^{* *}$ & \\
Utility value & $.10^{*}$ & $-.17^{* *}$ & $.46^{* *}$ & \\
Self-perceptions & $.24^{* *}$ & $-.49^{* *}$ & $.57^{* *}$ & $.32^{* *}$ \\
\hline
\end{tabular}

${ }^{*} p<.05 .{ }^{* *} p<.01$. 
Academic choices consisted of planned and actual senior high course levels as well as career intentions. Senior high plans were ascertained at Grades 9 and 10 via students checking boxes to indicate which level of mathematics they planned to study for Grade 11. At Grade 11, students were asked which course level they were actually studying. Career plans were assessed using an open-ended question asking what career students intended pursuing. The mathematics relatedness of those plans was quantified using $\mathrm{O}^{*} \mathrm{NET}^{\mathrm{TM}}$ 98: The Occupational Information Network (US Department of Labor Employment and Training Administration, 1998) into one of "none", "any", "average", through to "high".

\section{Procedure}

The study was conducted with informed student and parent consent, and the approval of the School Principals and formal University and Departmental ethical bodies. Administration by the researcher was in the regular classroom to maximise ecological validity, with the exception of the final wave, which was administered to a larger group in each school's hall.

\section{Analyses}

Gender differences in maths participation choices at each Grade were analysed using dominance analysis (Cliff, 1993), summarised by the $d$ statistic. Proportions of each gender nominating courses and careers involving varying degrees of mathematics were of interest, and $d$ measures the extent to which one sample distribution lies above another. $d$ is a point estimate of the population parameter $\delta$, where $d$ is the difference in probabilities between any two randomly selected members selected one from each group. $d$ measures the probability that any selected member of group one will lie above any selected member of group two. The $d$ statistic also makes no distributional assumptions, and so was appropriate to the present data (Cliff, 1993). Since the $d$ distribution is asymptotically equivalent to the $z$ distribution, inferential statistics can be derived by converting $d$ to a $z$ score and comparing this with the appropriate critical value.

MANOVA tested for gender differences on Grade 9 maths achievement, and Grade 10 maths-related self-perceptions, intrinsic and utility values, and perceived maths difficulty. Regression analyses examined the influences of prior mathematical achievement, perceived difficulty, intrinsic and utility values, and self-perceptions related to maths, on Grade 11 maths course selections and maths-related career intentions (prior multiple discriminant analyses established that one discriminant function explained $88 \%$ and $94 \%$ of the variability in each of Grade 11 course selections and maths-related career plans respectively; see Watt, 2002). Preliminary visual inspection of scatterplots indicated linear regression to be appropriate for relationships between boys' and girls' motivations and maths participation outcomes in all cases but one: a quadratic interaction of gender and utility value on maths-related career plans appeared likely, and so this term was also modelled in the regression analysis. ${ }^{2}$ 


\section{Results}

\section{Gender Differences in Participation}

Robust gender differences were evident in both planned and actual senior high maths participation, where boys planned to participate in the higher levels of mathematics more than girls through Grades 9 and 10 and, further, selected and undertook higher maths course levels than girls at Grade 11 (see Figure 2). Projected career intentions also showed that boys planned to pursue maths-related careers more than girls (Figure 3). These differences were remarkably robust in terms of their consistency

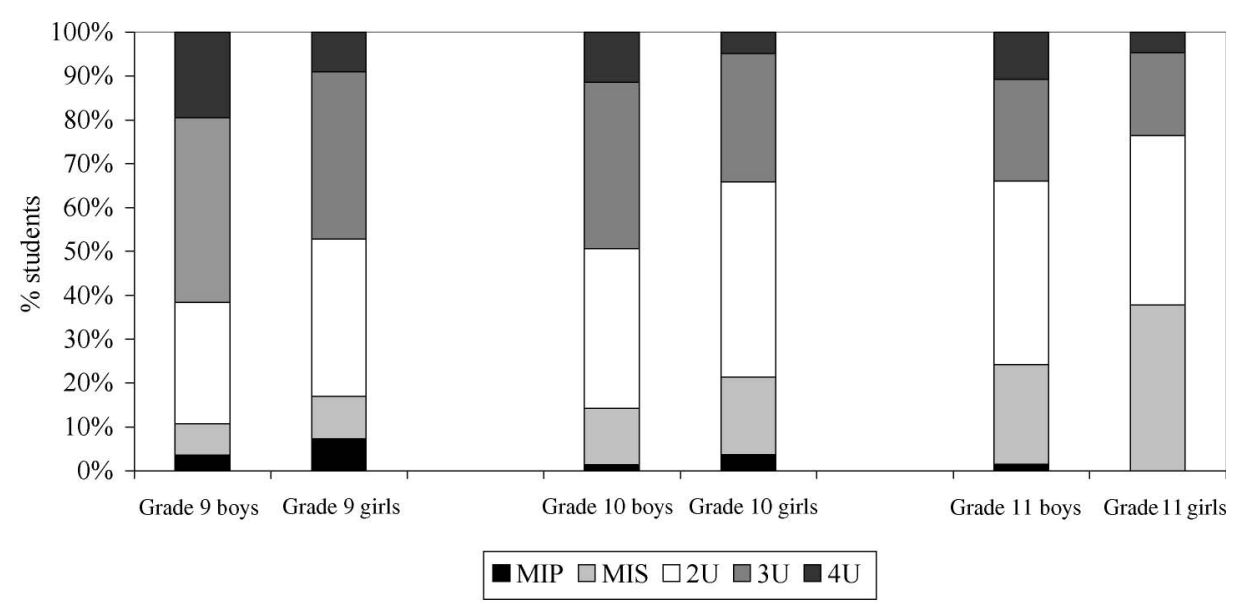

Figure 2. Gendered senior high planned and actual maths course selections.

Note: Grade 11 results reflect students' actual course levels

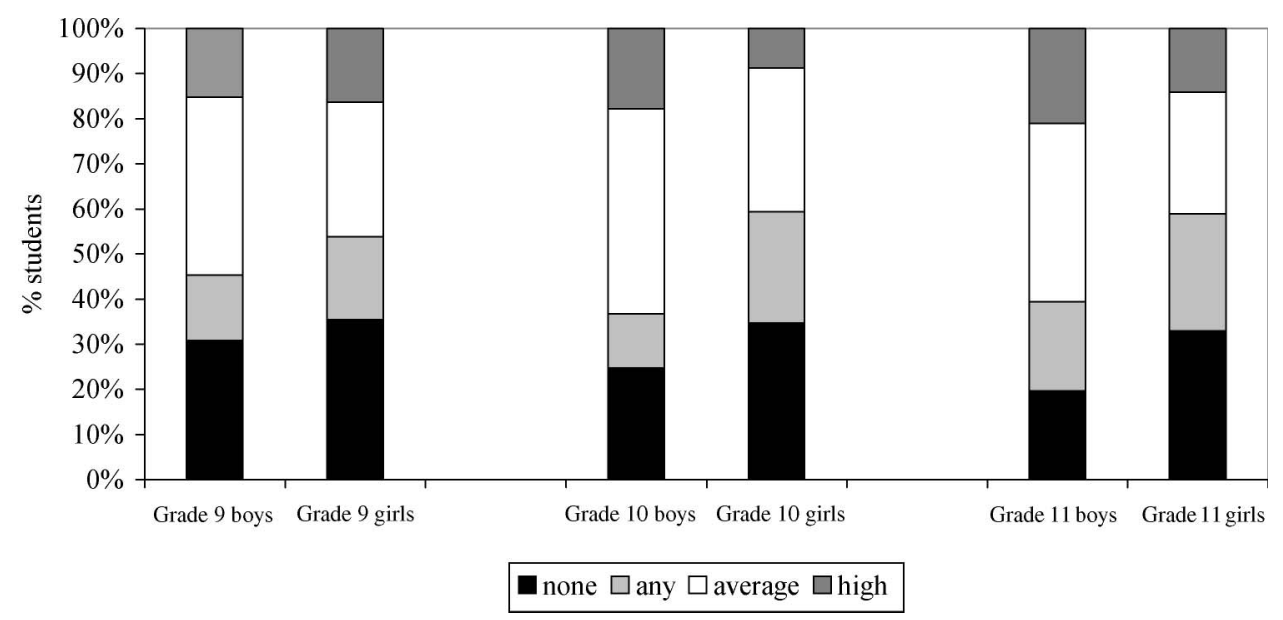

Figure 3. Gendered maths-related career plans 
across successive years $(\rho=.60, .73$ for Grade 11 math course choices between Grades 9 to 10 , and Grades 10 to $11 ; \rho=.50$, .49 for maths-related career plans).

Differences in proportions favouring boys were statistically significant at each grade level for planned and actual senior high course selections, with $d$ ranging from .19 to .18 (see Table 4). Significant $d$ values favouring boys were also evident for mathsrelated career plans, with $d$ ranging from .21 to .23, except at Grade 9 where this effect did not achieve statistical significance (Table 3 ).

\section{Gender, Motivations, and Achievement in Maths}

Boys rated their self-perceptions of mathematical talent and expected success significantly higher than did girls $(F(1,440)=24.36 p<.001$, see Figure 4$)$. This occurred despite equivalent levels of prior mathematical achievement for boys and girls $(F(1,440)=.70 p=.40$, boys: $M=21.26 S D 4.65$, girls: $M=21.62 S D 4.34)$. Boys also rated their intrinsic value higher $(F(1,440)=15.36 p<.001$, see Figure 4$)$, and their perceptions about the difficulty of maths lower than did girls $(F(1,440)=5.61$ $p=.018$, see Figure 4$)$. Boys and girls rated the utility value of maths similarly $(F(1,440)=1.77 p=.184$, see Figure 4$)$.

\section{Influences on Maths Participation Choices}

Senior high maths course levels selected by students at Grade 11 were influenced by prior mathematical achievement $(\beta=.31)$, intrinsic value $(\beta=.20)$, and selfperceptions related to maths $(\beta=.15)$ (see Table 5). Students who had higher levels of prior achievement in maths selected higher maths course levels, and this was the strongest measured influence on their senior high enrolments. Students with higher intrinsic values $(\beta=-.20)$ and self-perceptions of mathematical talent and success expectancies $(\beta=-.15)$ also subsequently selected higher maths course levels, even when prior mathematical achievement was controlled.

Table 4. Gender differences in academic choices as measured by the $d$-statistic for senior high mathematics courses and career mathematics relatedness

\begin{tabular}{lcccc}
\hline Academic choices & & Grade 9 & Grade 10 & Grade 11 \\
\hline Senior high course level & $d$ & $.190^{*}$ & $.185^{*}$ & $.175^{*}$ \\
& $\sigma_{\mathrm{d}}$ & .055 & .056 & .059 \\
Career choice & $z$ & 3.46 & 3.30 & 2.97 \\
& $d$ & .059 & $.225^{*}$ & $.207^{*}$ \\
& $\sigma_{\mathrm{d}}$ & .063 & .061 & .064 \\
& $z$ & .94 & 3.69 & 3.23 \\
\hline
\end{tabular}

Note: Positive values correspond to higher ratings for boys, negative values to higher ratings for girls.

*denotes significance at $p<.05$. 


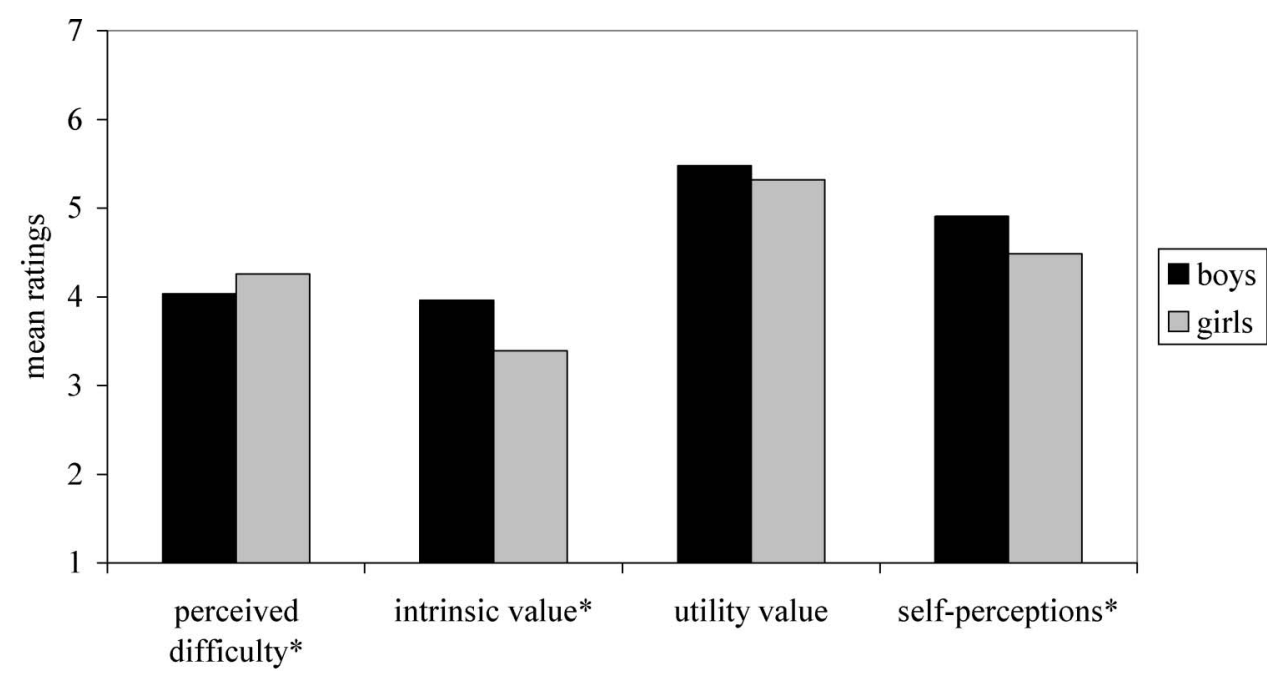

Figure 4 . Gendered motivations related to maths. ${ }^{*} p<.05$

Girls had lower maths-related self-perceptions $(\beta=-.20)$ and intrinsic value $(\beta=-.15)$ than boys, and there was no gender effect on utility value. Prior achievement impacted positively on subsequent self-perceptions $(\beta=.21)$ and intrinsic value $(\beta=.25)$, although not utility value. Girls also perceived maths as more difficult than boys $(\beta=.12)$, which then related to their lower maths-related self-perceptions $(\beta=-.48)$, and intrinsic $(\beta=-.43)$, and utility values $(\beta=-.14)$, independently of their prior mathematical achievement. In this way, and as posited in the ExpectancyValue framework, task difficulty perceptions exerted indirect effects on senior high maths participation choices, via their influence on self-perceptions and intrinsic value (indirect effects of $\beta=.07$ and $\beta=.09$ respectively), and did not impact directly on maths enrolment choices. Utility value did not affect senior high maths enrolments, and consequently neither did perceived difficulty exert an indirect effect on maths enrolments via utility value.

The extent to which students intended pursuing a maths-related career was directly impacted only by level of senior high maths course enrolment $(\beta=.35)$. Other measured motivational influences exerted indirect effects via their influences on senior high maths course enrolments described above. The anticipated quadratic interaction of gender and utility value did not attain statistical significance $(p=.20 \beta=.16)$, although this may have related to low power.

Consequently, ANOVA was employed based on a triad split for utility values (cutoffs at values of 5.00 and 6.00), in order to improve statistical power. This analysis identified an interaction effect of gender and maths utility value as shown in Figure 5 $(F(2,334)=4.72 p=.01$; boys: low $M=1.13 S D=.86$, mid $M=1.79 S D=.95$, high $M=1.70 S D=.90$; girls: low $M=1.07 S D=1.04$, $\operatorname{mid} M=.89 S D=.81$, 
Table 5. Summary of regression analyses predicting maths-related educational and occupational participation

\begin{tabular}{|c|c|c|c|c|}
\hline Dependent & Predictor & $\beta$ & $\mathrm{B}$ & S.E \\
\hline $\begin{array}{l}\text { Prior achievement } \\
\quad \text { (Grade 9) } \\
\quad\left(\text { Adj. } R^{2}=.00 \text { ) }\right.\end{array}$ & Gender & .05 & .46 & .47 \\
\hline $\begin{array}{l}\text { Perceived difficulty } \\
\quad \text { (Adj. } R^{2}=.01 \text { ) }\end{array}$ & $\begin{array}{l}\text { Gender } \\
\text { Prior achievement }\end{array}$ & $\begin{array}{l}.12^{*} \\
.01\end{array}$ & $\begin{array}{l}.25 \\
.00\end{array}$ & $\begin{array}{l}.12 \\
.01\end{array}$ \\
\hline $\begin{array}{l}\text { Intrinsic value } \\
\quad\left(\text { Adj. } R^{2}=.27\right)\end{array}$ & $\begin{array}{l}\text { Gender } \\
\text { Prior achievement } \\
\text { Perceived difficulty }\end{array}$ & $\begin{array}{r}-.15 * * \\
.25 * * \\
-.43 * *\end{array}$ & $\begin{array}{r}-.50 \\
.09 \\
-.66\end{array}$ & $\begin{array}{l}.15 \\
.02 \\
.07\end{array}$ \\
\hline $\begin{array}{l}\text { Utility value } \\
\left.\quad \text { (Adj. } R^{2}=.02\right)\end{array}$ & $\begin{array}{l}\text { Gender } \\
\text { Prior achievement } \\
\text { Perceived difficulty }\end{array}$ & $\begin{array}{l}-.06 \\
.08 \\
-.14^{* *}\end{array}$ & $\begin{array}{r}-.17 \\
.02 \\
-.17\end{array}$ & $\begin{array}{l}.14 \\
.02 \\
.07\end{array}$ \\
\hline $\begin{array}{l}\text { Self-perceptions } \\
\quad\left(\text { Adj. } R^{2}=.32 \text { ) }\right.\end{array}$ & $\begin{array}{l}\text { Gender } \\
\text { Prior achievement } \\
\text { Perceived difficulty }\end{array}$ & $\begin{array}{r}-.20 * * \\
.21 * * \\
-.48 * *\end{array}$ & $\begin{array}{r}-.38 \\
.04 \\
-.44\end{array}$ & $\begin{array}{l}.09 \\
.01 \\
.04\end{array}$ \\
\hline $\begin{array}{l}\text { Senior high math } \\
\text { course enrolment } \\
\text { (Adj. } R^{2}=.24 \text { ) }\end{array}$ & $\begin{array}{l}\text { Gender } \\
\text { Prior achievement } \\
\text { Perceived difficulty } \\
\text { Intrinsic value } \\
\text { Utility value } \\
\text { Self-perceptions }\end{array}$ & $\begin{array}{l}-.09 \\
.31^{* *} \\
-.01 \\
.20^{* *} \\
.02 \\
.15^{*}\end{array}$ & $\begin{array}{r}-.16 \\
.07 \\
-.01 \\
.12 \\
.02 \\
.15\end{array}$ & $\begin{array}{l}.10 \\
.01 \\
.06 \\
.04 \\
.05 \\
.07\end{array}$ \\
\hline $\begin{array}{l}\text { Maths-related } \\
\text { career plans } \\
\quad\left(\text { Adj. } R^{2}=.21 \text { ) }\right.\end{array}$ & $\begin{array}{l}\text { Gender } \\
\text { Prior achievement } \\
\text { Perceived difficulty } \\
\text { Intrinsic value } \\
\text { Utility value } \\
\text { Gender } \times \text { utility value } \\
\text { Gender } \times \text { utility value squared } \\
\text { Self-perceptions } \\
\text { Senior high math course enrolment }\end{array}$ & $\begin{array}{r}-.05 \\
.03 \\
.04 \\
.03 \\
.09 \\
-.18 \\
.16 \\
.12 \\
.35^{* *}\end{array}$ & $\begin{array}{r}-.10 \\
.01 \\
.04 \\
.02 \\
.08 \\
-.21 \\
.07 \\
.14 \\
.42\end{array}$ & $\begin{array}{l}.20 \\
.02 \\
.07 \\
.05 \\
.06 \\
.14 \\
.06 \\
.09 \\
.08\end{array}$ \\
\hline
\end{tabular}

${ }^{*} p<.05 .{ }^{* *} p<.01$.

high $M=1.52 S D=1.00)$. The interaction effect was due to boys with mid maths utility values having statistically significantly more highly maths-related career plans than girls with mid utility values $(F(1,103)=26.39 p<.001)$, while boys and girls within each of the low $(F(1,122)=.12 p=.73)$ and high $(F(1,165)=1.35 p=.25)$ utility value groups had similarly maths-related career plans. Among boys, those with mid and high utility values planned similarly maths-related careers, while those with low utility values planned significantly less maths-related careers $(F(2,221)=10.52$ $p<.001$, Tukey's HSD post hoc tests showed the low group differed from each of the mid and high groups with $p<.001$, while the mid and high groups were similar with $p=.79$ ). Among girls, those with low and mid utility values planned careers of similar 


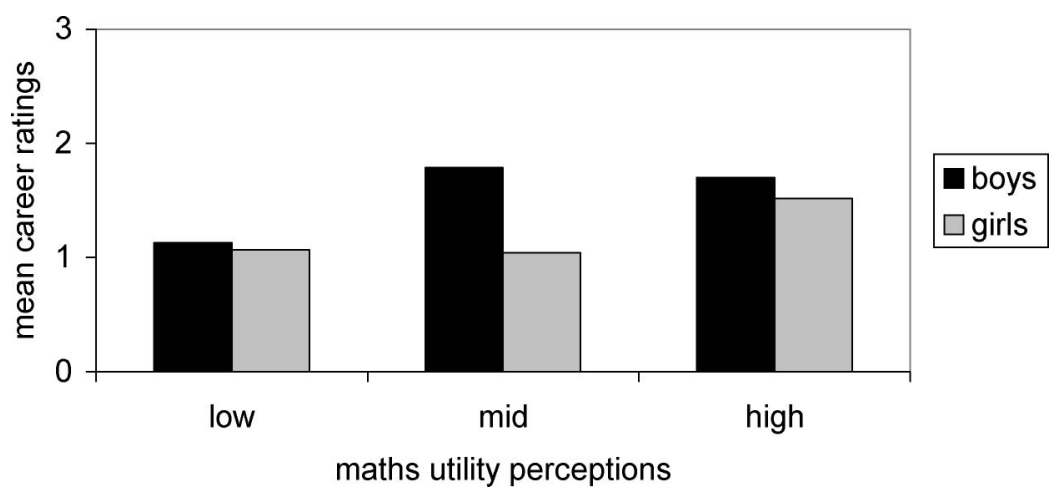

Figure 5. Maths-relatedness of boys' and girls' career plans by level of maths utility value

maths-relatedness, while those with high utility values planned significantly more highly maths-related careers than either the mid or low utility value groups $(F(2,169)=6.54 p=.002$, Tukey's HSD post hoc tests showed the high group differed from each of the low $[p=.02]$ and mid groups $[p=.002]$, while the low and mid groups were similar with $p=.63$ ). This implies that maths-related career choice for girls is based on utility value only when this is high, whereas boys with both high and mid levels of utility value planned to pursue highly maths-related careers.

\section{Discussion}

Robust gender differences exist within the maths-related educational and occupational choices for these Australian adolescents. Boys both planned and subsequently undertook higher levels of maths than girls in senior high school. Boys also planned more highly maths-related career than girls. These gendered educational and occupational choices related to maths were substantially explained by adolescents' motivations, over and above their prior mathematical performance.

Maths-related self-perceptions (of talent and expected success) and intrinsic values emerged as the key predictors of students' subsequent choices for maths participation in senior high course selections, as predicted by the Expectancy-Value model of Eccles and colleagues (Eccles (Parsons) et al., 1983; Wigfield \& Eccles, 2000). As with studies conducted by Eccles and her colleagues (see Eccles (Parsons) et al., 1983), no direct influence of task difficulty perceptions on choice outcomes was identified. Girls' perceptions of maths as being more difficult did, however, have flow-on effects to their lower maths-related self-perceptions and intrinsic value, which in turn impacted on their lower senior high maths course participation.

Maths-related career plans were strongly impacted by adolescents' senior high maths course level. There was also an interaction effect of gender and utility value, where girls who valued maths as highly useful were more likely to aspire to highly maths-related careers than other girls, while boys who valued maths as moderately through highly useful were equally likely to aspire to similarly highly maths-related 
careers. For girls then, valuing maths as highly useful is likely to lead to the choice of a maths-related career, while for boys, valuing maths as moderately useful is equally likely to influence maths-related career intentions. As argued by Eccles and her colleagues in the Expectancy-Value tradition (e.g., Eccles, 1984; Eccles, Midgley, \& Adler, 1984; Eccles (Parsons), 1984; Eccles (Parsons) et al., 1983; Ethington, 1991; Meece et al., 1990), values were indeed indicative of educational and occupational choices in maths. Different kinds of values were found to be relevant for different participation choices, with intrinsic value predicting senior high maths participation, and an interaction of utility value with gender predicting maths-related career plans.

Previous analyses involving the current data have established that boys maintained higher intrinsic value for maths and higher maths-related self-perceptions than girls throughout adolescence (see Watt, 2004). Since the present study has identified the importance of these factors in maths participation choices, both for senior high and planned careers, girls' lower levels are particularly problematic. We need to understand how it is that boys come to be more interested in and like maths more than girls; and also, why it is that girls perceive themselves as having less talent and lower expectations of success at math than boys, even though they perform similarly.

Since the usefulness of maths emerged as a salient concern in girls' career aspirations, educators could fruitfully focus on explicating the high utility value of maths (in general, in the workplace, and in the everyday world), to enhance the likelihood of girls pursuing highly maths-related careers. Previous analyses based on this sample have established that boys and girls had similarly declining perceptions for the utility of maths through adolescence (see Watt, 2004). It may be most important to guard against girls' declining maths utility values, because of the different ways that utility value influenced maths-related career plans for boys and girls. For girls, only high utility values related to mathematical career plans, while mid through high utility values were related for boys. It is therefore particularly important to focus on ameliorating against declines in the utility value of maths for girls, in order to promote their participation in mathematical careers. Although self-perceptions of mathematical talent and expectations for success, and intrinsic value did not impact directly on maths-related career plans, they did affect occupational outcomes indirectly, via their influences on senior high course enrolments, and consequently are important to consider in relation to gendered occupational, as well as educational choices for maths participation. Jacobs and her colleagues (2002) have also provided suggestive evidence that changes in perceived mathematical competence shape changes in maths-related values.

Because senior high maths enrolment selections exerted the strongest influence on maths-related career plans, it appears that we need be particularly concerned about girls opting out of the "maths pipeline" at that point. In the NSW Australian system, this is in fact the first point at which adolescents are able to select the difficulty level of maths that they wish to undertake. In this context, we see that girls chose to opt out of the more difficult levels of maths at their first real opportunity. These choices, in turn, 
had strong implications for these young adults' intentions to pursue maths-related careers, consistent with the notion of maths as a "critical filter". It may also be that students make decisions about their level of senior high maths involvement based in part on their concurrent career aspirations.

Operationalising the extent of boys' and girls' maths participation choices, both for senior high course selections and maths-related career intentions, has enabled a more fine-grained analysis of the extent of gendered maths participation in schooling and career contexts than previous studies have been able to provide. Across a sample of upper-middle class secondary school students in metropolitan Sydney, Australia, it is clear that robust and persistent gender imbalances in maths participation choices remain. A limitation of the study is its reliance upon career intentions rather than actual future career choices, which would be an important extension for future research.

Should similar participation of males and females in maths be our goal? Shapka, Domene, and Keating (this issue) contend that the prestige of men's and women's occupations may be the more important dimension to consider, rather than the type of occupation. Either way, the persistent gender imbalance in choices for maths participation appears extraordinarily robust across contexts and time, and remains a social phenomenon, regardless of whether we consider it a social problem. Given current shortages of people entering maths-related careers in general, it is clearly important to target both males' and females' choices for maths participation. Key to addressing this problem will be a focus on girls' liking for and interest in maths, their self-perceptions of mathematical talent and expectations for success, and their valuation of the utility of maths. Continued investigations into the origins and sources of gender differences in maths intrinsic values and self-perceptions in particular promise to shed further light on the persistent issue of gendered mathematical participation.

\section{Notes}

1. A new system of senior high HSC course levels was introduced in 2000, so the statistics reported here in fact span the entire period of this course structure.

2. To model this effect, utility value was centred about zero, contrasts of -.5 and .5 represented males and females respectively, and gender $\times$ utility value, and gender $\times$ utility value squared were incorporated as predictors of maths-related career choices.

\section{References}

Australian Bureau of Statistics (ABS). (1991). Index of education and occupation (catalogue No. 2912.0). Sydney, Australia: Author.

Australian Council for Educational Research (ACER). (1984). Progressive achievement tests of mathematics. Melbourne, Australia: Author.

Board of Studies. (1991). 1991 Higher School Certificate examination statistics. Sydney: Author.

Board of Studies. (1992). 1992 Higher School Certificate examination statistics. Sydney: Author.

Board of Studies. (1993). 1993 Higher School Certificate examination statistics. Sydney: Author.

Board of Studies. (1994). 1994 Higher School Certificate examination statistics. Sydney: Author. 
Board of Studies. (1995). 1995 Higher School Certificate examination statistics. Sydney: Author. Board of Studies. (1996). 1996 Higher School Certificate examination statistics. Sydney: Author. Board of Studies. (1997). 1997 Higher School Certificate examination statistics. Sydney: Author. Board of Studies. (1998). 1998 Higher School Certificate examination statistics. Sydney: Author. Board of Studies. (1999). 1999 Higher School Certificate examination statistics. Sydney: Author.

Bong, M. (2001). Role of self-efficacy and task-value in predicting college students' course performance and future enrollment intentions. Contemporary Educational Psychology, 26, $553-570$.

Bornholt, L. J., Goodnow, J. J., \& Cooney, G. H. (1994). Influences of gender stereotypes on adolescents' perceptions of their own achievement. American Educational Research fournal, 31, $675-692$.

Bridgeman, B., \& Wendler, C. (1991). Gender differences in predictors of college mathematics performance and in college mathematics course grades. Fournal of Educational Psychology, 83, $275-284$

Cliff, N. (1993). Dominance statistics: Ordinal analyses to answer ordinal questions. Psychological Bulletin, 114, 494-509.

Eccles, J. S. (1984). Sex differences in achievement patterns. In T. Sonderegger (Ed.), Nebraska Symposium on Motivation (Vol. 32, pp. 97-132). Lincoln, NE: University of Nebraska Press.

Eccles, J. S. (1985). A model of student enrolment decisions. Educational Studies in Mathematics, 16, $311-314$

Eccles, J. S., Adler, T. F., \& Meece, J. L. (1984). Sex differences in achievement: A test of alternate theories. Fournal of Personality and Social Psychology, 46, 26-43.

Eccles, J. S., Midgley, C., \& Adler, T. (1984). Grade-related changes in the school environment: Effects on achievement motivation. In J. G. Nicholls (Ed.), Advances in motivation and achievement: The development of achievement motivation (Vol. 3, pp. 283-331). Greenwich, CT: JAI Press Inc.

Eccles, J. S., \& Wigfield, A. (1995). In the mind of the actor: The structure of adolescents' achievement task values and expectancy-related beliefs. Personality and Social Psychology Bulletin, 21, 215-225.

Eccles (Parsons), J. S. (1984). Sex differences in mathematics participation. In M. W. Steinkamp \& M. L. Maehr (Eds.), Advances in motivation and achievement: Vol. 2. Women in science (pp. 93-137). Greenwich, CT: JAI Press.

Eccles (Parsons), J., Adler, T. F., Futterman, R., Goff, S. B., Kaczala, C. M., Meece, J. L., \& Midgley, C. (1983). Expectancies, values, and academic behaviors. In J. T. Spence (Ed.), Achievement and achievement motivation (pp. 75-146). San Francisco: W. H. Freeman.

Ethington, C. A. (1991). A test of a model of achievement behaviors. American Educational Research Fournal, 28, 155-172.

Forgasz, H. J., \& Leder, G. C. (2001). The Victorian Certificate of Education - A gendered affair? Australian Educational Reserearcher, 28(2), 53-66.

Foster, V. (2000). Gender, schooling achievement and post-school pathways: Beyond statistics and populist discourse. In S. Dinham \& C. Scott (Eds.), Teaching in context (pp. 82-96). Camberwell, Victoria: Australian Council for Educational Research.

Green, D. R. (1974). The aptitude-achievement distinction. California: McGraw-Hill.

Heller, K. A., \& Parsons, J. E. (1981). Sex differences in teachers' evaluative feedback and students' expectancies for success in mathematics. Child Development, 52, 1015-1019.

Jacobs, J. E., Lanza, S., Osgood, D. W., Eccles, J. S., \& Wigfield, A. (2002). Changes in children's self-competence and values: Gender and domain differences across grades one through twelve. Child Development, 73, 509-527.

Leder, G. C. (1992). Mathematics and gender: Changing perspectives. In D. A. Grouws (Ed.), Handbook of research on mathematics teaching and learning (pp. 597-622). New York: Macmillan. 
Leder, G., \& Forgasz, H. (1992). Gender: A critical variable in mathematics education. In B. Atweh \& J. Watson (Eds.), Research in mathematics education in Australasia 1988-1991 (pp. 67-95). University of Technology, Qld: Mathematics Education Research Group of Australasia.

Leder, G. C., Forgasz, H. J., \& Solar, C. (1996). Research and intervention programs in mathematics education: A gendered issue. In A. Bishop, K. Clements, C. Keitel, J. Kilpatrick, \& C. Laborde (Eds.), International handbook of mathematics education (Part 2, pp. 945-985). Dordrecht, The Netherlands: Kluwer.

Lips, H. M. (1992). Gender- and science-related attitudes as predictors of college students' academic choices. Fournal of Vocational Behavior, 40(1), 62-81.

MacCann, R. (1995). Sex differences in participation and performance at the NSW Higher School Certificate after adjustment for the effects of differential selection. Australian fournal of Education, 39, 163-188.

Meece, J. L., Eccles (Parsons), J. S., Kaczala, C., Goff, S. B., \& Futterman, R. (1982). Sex differences in math achievement: Toward a model of academic choice. Psychological Bulletin, $91,324-348$.

Meece, J. L., Wigfield, A., \& Eccles, J. S. (1990). Predictors of math anxiety and its consequences for young adolescents' course enrollment intentions and performances in mathematics. Fournal of Educational Psychology, 82, 60-70.

O'Doherty, S. (1994). Inquiry into boys' education 1994. Challenges and opportunities: A discussion paper. Canberra, NSW: Ministry of Education, Training and Youth Affairs, NSW.

Osipow, S. H., \& Fitzgerald, L. F. (1996). Theories of career development (4th ed.). London: Allyn \& Bacon.

Schafer, J. L. (1997). Analysis of incomplete multivariate data. London: Chapman \& Hall.

Sells, L. W. (1980). Mathematics: The invisible filter. Engineering Education, 70, 340-341.

Simpkins, S. D., Davis-Kean, P. E., \& Eccles, J. S. (in press). Math and science motivation: A longitudinal examination of the links between choices and beliefs. Developmental Psychology.

Updegraff, K. A., Eccles, J. S., Barber, B. L., \& O’Brien, K. M. (1996). Course enrollment as self-regulatory behavior: Who takes optional high school math courses? Learning and Individual Differences, 8, 239-259.

US Department of Labor Employment and Training Administration. (1998). O*NET: The occupational information network. Washington, DC: US Government Printing Office.

Watt, H. M. G. (2002). Gendered achievement-related choices and behaviours in mathematics and English: The nature and influence of self-, task- and value perceptions. Unpublished $\mathrm{PhD}$ thesis, University of Sydney, Sydney, NSW, Australia.

Watt, H. M. G. (2004). Development of adolescents' self-perceptions, values, and task perceptions according to gender and domain in 7th- through 11th-grade Australian students. Child Development, $75,1556-1574$.

Watt, H. M. G. (2005). Explaining gendered math enrolments for NSW Australian secondary school students. New Directions in Child and Adolescent Development, 110(Winter), 15-29.

Wigfield, A. (1994). Expectancy-value theory of achievement motivation: A developmental perspective. Educational Psychology Review, 6, 49-78.

Wigfield, A., \& Eccles, J. (1992). The development of achievement task values: A theoretical analysis. Developmental Review, 12, 265-310.

Wigfield, A., \& Eccles, J. S. (2000). Expectancy-value theory of achievement motivation. Contemporary Educational Psychology, 25, 68-81.

Zevenbergen, R. (1998). Gender, media, and conservative politics. In C. Keitel (Ed.), Social justice and mathematics education: Gender, class, ethnicity and the politics of schooling (pp. 59-68). Berlin, Germany: Freie Universität Berlin. 